\title{
Iron speciation in human cancer cells by K-edge total reflection X-ray fluorescence-X-ray absorption near edge structure analysis
}

\author{
Zs. Polgári ${ }^{\text {a }}$, F. Meirer ${ }^{\text {b,c }}$, S. Sasamori ${ }^{\text {b }}$, D. Ingerle ${ }^{\text {b }}$, G. Pepponi ${ }^{c}$, C. Streli $^{\text {b }}$, K. Rickers $^{\text {d }}$, A. Réti ${ }^{\text {e }}$, B. Budai $^{\text {e }}$, \\ N. Szoboszlai a , G. Záray ${ }^{\text {a,* }}$

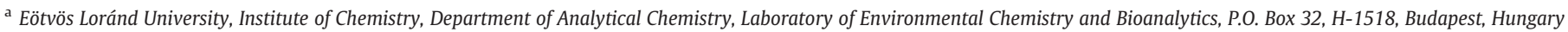 \\ ${ }^{\mathrm{b}}$ Institute of Atomic and Subatomic Physics, Vienna University of Technology, Vienna, Austria \\ c MiNALab, CMM-irst, Fondazione Bruno Kessler, Povo, Trento, Italy \\ ${ }^{\mathrm{d}}$ Hamburger Synchrotronstrahlungslabor at DESY, Hamburg, Germany \\ e Department of Clinical Research, National Institute of Oncology, Budapest, Hungary
}

\section{A R T I C L E I N F O}

\section{Article history:}

Received 3 June 2010

Accepted 25 March 2011

Available online 2 April 2011

\section{Keywords}

XANES

TXRF

Iron

Cancer cell

\begin{abstract}
A B S T R A C T
X-ray absorption near edge structure (XANES) analysis in combination with synchrotron radiation induced total reflection X-ray fluorescence (SR-TXRF) acquisition was used to determine the oxidation state of Fe in human cancer cells and simultaneously their elemental composition by applying a simple sample preparation procedure consisting of pipetting the cell suspension onto the quartz reflectors.

XANES spectra of several inorganic and organic iron compounds were recorded and compared to that of different cell lines. The XANES spectra of cells, independently from the phase of cell growth and cell type were very similar to that of ferritin, the main Fe store within the cell. The spectra obtained after $\mathrm{CoCl}_{2}$ or $\mathrm{NiCl}_{2}$ treatment, which could mimic a hypoxic state of cells, did not differ noticeably from that of the ferritin standard. After 5-fluorouracil administration, which could also induce an oxidative-stress in cells, the absorption edge position was shifted toward higher energies representing a higher oxidation state of Fe. Intense treatment with antimycin $\mathrm{A}$, which inhibits electron transfer in the respiratory chain, resulted in minor changes in the spectrum, resembling rather the N-donor Fe- $\alpha, \alpha^{\prime}$-dipyridyl complex at the oxidation energy of $\mathrm{Fe}(\mathrm{III})$, than ferritin. The incorporation of $\mathrm{Co}$ and $\mathrm{Ni}$ in the cells was followed by SR-TXRF measurements.
\end{abstract}

(c) 2011 Elsevier B.V. All rights reserved.

\section{Introduction}

Total reflection X-ray fluorescence (TXRF) spectrometry is a perfect tool for elemental trace and microanalysis [1], especially for biological applications [2]. As the total reflection geometry offers very high sensitivities for elemental analysis by X-ray fluorescence technique, this characteristic can be used to apply this set up for the speciation of minute amounts of metals [3]. The performance of TXRF is drastically increased if synchrotron radiation (SR) is used as source of X-rays due to the outstanding properties of SR like high brilliance and broad energy range [4]. The SR-TXRF method offers detection limits in the femtogram range for transition metals using a multilayer monochromator at a bending magnet beamline [5-7]. Applying a crystal monochromator instead of a multilayer enables X-ray absorption measurements to gain chemical information on a specific element of interest. Here, the sensitivity is decreased due to the fact that the flux delivered by a crystal monochromator (e.g. $\mathrm{Si}(111)$ ) is

\footnotetext{
* Corresponding author. Tel.:+36 13722607361.

E-mail address: zaray@ludens.elte.hu (G. Záray).
}

about two orders of magnitude lower than that of a multilayer. However, this modified setup still offers sufficient sensitivity for elemental analysis at the nanogram per milliliter (ppb) level [8-11] and therefore allows elemental analysis by SR-TXRF and determination of the oxidation state of a certain element by total reflection X-ray fluorescence-X-ray absorption near edge structure (TXRF-XANES) analysis using the same experimental setup at the same beamline.

The determination of trace elements in cancer cells is essential for the better understanding of biological functions. Trace elements for example ( $\mathrm{Ca}, \mathrm{Mg}$, Fe, $\mathrm{Cu}, \mathrm{Zn}$ etc.) are involved in biological processes, can be incorporated in proteins, can be key factors of pathways and syntheses. Concentration of trace elements (mainly Fe, $\mathrm{Zn}$ and $\mathrm{Cu}$ ) in cancer cell lines has been measured by laboratory scale TXRF spectrometers. Gonzalez et al. [12] determined the intracellular metal content of six different mammalian cell lines (3T3, N2A, B12, Caco-2, HeLa and HepG2). Copper concentrations of the cells were found to be between 0.32 and $1.35 \mathrm{nmol} / \mathrm{mg}$ protein, Fe: 3.20 $4.28 \mathrm{nmol} / \mathrm{mg}$ protein and $\mathrm{Zn}: 5.53-9.03 \mathrm{nmol} / \mathrm{mg}$ protein. Two different cell lines (HCA-7 and HT-29) have been investigated by Szoboszlai et al. [13]. Cu concentrations were found in this study 8.2$30.1 \mathrm{mg} / \mathrm{g}$ dry weight or $13.8-54.8 \mathrm{ng} / \mathrm{mg}$ protein, Fe concentrations: 
$61.2-156.0 \mathrm{mg} / \mathrm{g}$ dry weight or $115.2-283.6 \mathrm{ng} / \mathrm{mg}$ protein, $\mathrm{Zn}$ concentrations: $62.3-177.0 \mathrm{mg} / \mathrm{g}$ dry weight or $118.3-322.0 \mathrm{ng} / \mathrm{mg}$ protein. According to these studies, it can be concluded that cellular metal content varies depending on the cell lines; however, different studies used different types of references, i.e. number of cells, protein content or dry weight when reporting their results, which hampers comparison. In the presented study about $10^{4}-10^{5}$ cells were transferred onto carrier plates. Due to the extremely high sensitivity of the SR-TXRF technique the number of cells placed onto the carrier plate could be reduced by $2-3$ orders of magnitude using very diluted cell suspensions (140 cells/ $\mu \mathrm{l})$ [14].

Different XANES studies have been used to provide information about the oxidation state of metal ions in human tissue samples [15], however, only a few XANES investigations were focused on cellular samples [16-23].

Kwiatek et al. studied different prostate cancer cell lines such as DU-145, PC-3 and LNCaP [16]. In order to fix the cells paraformaldehyde solution $(2 \% \mathrm{w} / \mathrm{w})$ was used. $20 \mu \mathrm{l}$ aliquots of cell suspension were placed onto $1.5 \mu \mathrm{m}$ thick Mylar foil. The XANES measurements in fluorescent mode on K-edge of Zn were performed in air at room temperature. The Zn K-edge XANES spectra for all cell lines showed very similar features. The same research group published another method using transmission mode XANES at room temperature, in vacuum. They demonstrated that sulfur K-edge position for cultured cell lines does not depend on different fixing procedures [17].

Hall et al. [18] studied the cellular reduction of Pt(IV) complexes in parental A2780 ovarian cancer cells. The cells were treated with either the Pt(II) complexes or Pt(IV) complexes at a concentration of $50 \mu \mathrm{M}$. Cells were isolated, washed, and freeze-dried after 2 and $24 \mathrm{~h}$ of treatment. The XANES spectra were registered at a temperature of $-261^{\circ} \mathrm{C}$

Harris et al. [19] monitored the Cr oxidation state by micro-XANES in A549 human lung adenocarcinoma epithelial cells treated with $\mathrm{Cr}(\mathrm{VI})$. Small aliquots of cell suspensions $(1.0 \mu \mathrm{l})$ were placed onto Formvar films supported by 200 -mesh gold Finder grids. Five grids were prepared per sample containing 100-200 cells per grid. The same group performed a study about the oxidation state of $\mathrm{Cr}$ in different cancer cell lines (A549, HepG2, V79 and C2C12) and in subcellular fractions after treatment with $\mathrm{Cr}(\mathrm{VI})$ [20]. For separation of subcellular fractions (high- and low-molecular mass fractions), $\mathrm{Cr}(\mathrm{VI})$-treated or untreated cells $\left(\sim 5 \times 10^{7}\right.$ cells per sample) were lysed at $0{ }^{\circ} \mathrm{C}$ in a lysis buffer followed by different centrifugation and filtration steps.

Bonnitcha et al. [21] used A2780 parental human ovarian carcinoma cells to determine the oxidation state of Co after treatment with $\mathrm{Co}$ (III) complexes. $70 \%$ ethanol solution was used for sample preparation. Freeze dried cell pellets were analyzed by packing the samples into polycarbonate sample holders.

Unfortunately there are only a few XANES report about speciation of Fe $[22,23]$. Ortega et al. investigated the iron oxidation state of IGROV-1 human ovarian carcinoma cells after doxorubicin treatment [22]. The cells were grown directly on thin Formvar films treated with an attachment factor (gelatin gel type $\mathrm{B}$ ), then the exponentially growing cells were treated with $25 \mu \mathrm{M} \mathrm{FeSO}$, then with $2 \mu \mathrm{M}$ doxorubicin. The Fe K-edge structure was studied in fluorescence mode after cryofixation of cells in isopentane chilled with liquid nitrogen. The XANES spectra of doxorubicin-treated and control cells were almost similar. Micro-XANES experiments were performed by Bacquart et al. [23] on iron treated PC-12 rat neuronal cells. In this case the cells in their frozen hydrated state were found to be the best form avoiding the beam damage originating from high photon flux.

In the literature, several authors studied the influence of oxidative stress and induced hypoxia (Antimycin, Ni and Co treatments) on iron metabolism [24-27], however they had no information about the possible change of iron oxidation state. Considering the above-mentioned experimental works and results, there is a need to follow the change of coordination and oxidative state of iron after these treatments.
The aim of our study was to develop a simple analytical procedure to receive information about the concentration of different elements and additionally about the oxidation states and the molecular environment of iron in human cells by SR-TXRF and XANES techniques, respectively. For that purpose the influence of ligands on the XANES spectra of different iron containing standards and the XANES spectra of four different cancer cells with and without treatments were studied and evaluated.

\section{Experimental}

\subsection{Instrumentation}

The Fe K-edge XANES measurements in fluorescence mode and grazing incidence geometry were carried out using the setup at the beamline $L$ at the Hamburger Synchrotronstrahlungslabor (HASYLAB) at DESY $[9,28]$. All measurements were performed in vacuum. A Si (111) double crystal monochromator was used for selecting the energy of the exciting beam from the continuous X-ray spectrum emitted by the $1.2 \mathrm{~T}$ bending magnet at beamline L. The primary beam was collimated to $100 \mu \mathrm{m} \times 2300 \mu \mathrm{m}$ (horizontal $\times$ vertical) by a crossslit system. The incident X-ray intensity was monitored with an ionization chamber.

During the measurements the excitation energy was tuned in varying steps $(15,10,5$ and $1 \mathrm{eV}$ in the pre- and post-edge regions and $0.5 \mathrm{eV}$ at the edge) across the iron K-edge at $7112 \mathrm{eV}$. The energy was scanned in the range $6995 \mathrm{eV}-7395 \mathrm{eV}$ with the following intervals and steps (start-stop/step): 6995-7045/10, 7045-7085/5, 7085$7095 / 1,7095-7145 / 0.5,7145-7195 / 1,7195-7305 / 5$ and 7305$7395 / 10$. At each energy a fluorescence spectrum was recorded by a Silicon Drift Detector (SDD, VORTEX $50 \mathrm{~mm}^{2}$, Radiant Detector Technologies) [29]. The distance between SDD and sample carrier was $1 \mathrm{~mm}$ [9]. The acquisition time for each spectrum was adjusted individually (in the range of 15 to $1 \mathrm{~s}$ ) for each sample to provide a sufficient signal to noise ratio within a reasonable measurement time. Each scan consisted of 210 single fluorescence spectra and was performed in the energy range of 7015-7500 eV. The detector was operated with a short shaping time to have higher throughput and the typical full width at half maximum for $\mathrm{Fe} K \alpha$ was $190 \mathrm{eV}$. Simultaneously, the absorption of an elemental iron foil was recorded in transmission mode for each scan. The first maximum of the derivative spectrum of the Fe metal foil scan was assumed to be at $7112 \mathrm{eV}$ (Fe K-edge).

As the critical angle of total reflection changes slightly $(<0.3 \mathrm{mrad}$ for a silicon substrate) during the energy scan, the incident angle of the primary X-ray beam was adjusted well below the critical angle ( $4.18 \mathrm{mrad}$ at $7500 \mathrm{eV}$ for a silicon substrate). In that way it can be assumed that the change of the critical angle during the XANES scans was not problematic for the measurement of the dried droplet samples (residues on surface) formed by the pipetted cell suspensions. Quartz carrier plates were used for the measurements. As a standard procedure, the cleanliness of all carrier plate was checked before the analysis. The surface of the dried samples on reflectors was checked by scanning electron microscopy (SEM), model AMRAY 1830 , in vacuum ( $\left.\mathrm{p}=10^{-4} \mathrm{mbar}\right)$ at $20 \mathrm{kV}$ accelerating potential and $0.1 \mathrm{nA}$ current intensity.

All absorption spectra have been analyzed within ATHENA which is included in the IFEFFIT program package for X-ray absorption spectroscopy analysis [30,31]. The background removal of the Fe K-edge profiles was done by the implemented AUTOBK algorithm and normalization was performed by edge step normalization [31] using normalization parameters in the pre-edge region in the range of -150 to $-30 \mathrm{eV}$ and in the post edge region in the range starting above $50 \mathrm{eV}$, with respect to the absorption edge. Multiple scans of the same sample have been merged by calculating the average at each point in the set. 


\subsection{Sample preparation}

\subsubsection{Cell lines and treatments}

All cell lines were cultured at the Department of Clinical Research, National Institute of Oncology, Budapest, Hungary (NIO). Cells were grown at $37{ }^{\circ} \mathrm{C}$ in a humidified atmosphere of $5 \% \mathrm{CO}_{2}$ in antibiotic-free medium supplemented with $10 \%$ fetal calf serum (Sigma). The HT-29 (human colon adenocarcinoma cell line - obtained from ECACC (European Collection of Cell Cultures, UK)), ZR-75-1 (human breast cancer cell line - obtained from the 1st Institute of Pathology and Experimental Cancer Research, Semmelweis University, Budapest, Hungary (1PS)) and HT-1080 (human fibrosarcoma cell line - obtained from 1PS) cells were cultured in RPMI-1640 (Roswell Park Memorial Institute) medium (Sigma). The MDA-MB-231 (human breast cancer cell line - obtained from the Department of Tumour Progression, NIO) cells were grown in DMEM (Dulbecco's Modified Eagle's Medium) medium (Sigma). $10^{5}-2 \times 10^{5}$ cells were treated at $80 \%$ confluency in 6-wellplates in sterile PBS (phosphate buffered saline) for $20 \mathrm{~min}$ or $4 \mathrm{~h}$. The experiments were carried out with the following drugs and chemicals: $1 \mathrm{mM} \mathrm{NiCl} 2\left(\mathrm{NiCl}_{2} \cdot 6 \mathrm{H}_{2} \mathrm{O}\right.$, Sigma), 2.4 and $57.6 \mathrm{mM} \mathrm{CoCl} 2\left(\mathrm{CoCl}_{2} \cdot 6 \mathrm{H}_{2} \mathrm{O}\right.$, Sigma), $10 \mathrm{mM} \mathrm{MgSO}_{4}\left(\mathrm{MgSO}_{4} \cdot 7 \mathrm{H}_{2} \mathrm{O}\right.$, Sigma $), 25$ and $300 \mu \mathrm{M}$ antimycin A (Sigma) and $130 \mu \mathrm{M}$ 5-fluorouracil (TEVA, Hungary).

Two different sample preparation protocols were checked:

(1) Quartz carrier plates were sterilized, placed into 6-well-plates and coated for $1 \mathrm{~h}$ with a) medium containing $10 \%$ fetal calf serum b) fibronectin (Sigma, concentration: $50 \mu \mathrm{g} / \mathrm{ml}$ ) and c) collagen type IV (Sigma, concentration: $50 \mu \mathrm{g} / \mathrm{ml}$ ). After the incubation cancer cells were cultured directly onto the quartz reflectors under culture conditions as described above. Following the treatments the cells grown on the carrier plates were gently washed by isotonic $\mathrm{NaCl}$ solution and the carriers were immediately placed into Ar-filled vessels.

(2) Treatments were carried out in 6-well-plates, after treatments the cells were harvested by trypsin (Sigma), washed twice with isotonic $\mathrm{NaCl}$ solution and centrifuged at $20.000 \mathrm{~g}$ at $4{ }^{\circ} \mathrm{C}$ for $15 \mathrm{~min}$. The cell number was counted using a Bürker chamber (MOM, Hungary). After the second centrifugation the cells were resuspended in $10 \mu \mathrm{l}$ isotonic $\mathrm{NaCl}$ solution and $5 \mu \mathrm{l}$ of cell suspension were pipetted onto quartz carrier plates. The estimated cell concentration was $10^{4}-2 \times 10^{4}$ cells/ $\mu$ l. The excess of isotonic $\mathrm{NaCl}$ solution was removed by pipetting. After this procedure the cell monolayer was controlled microscopically and dried at room temperature. All quartz carrier plates were placed into Ar-filled vessels and transported to the HASYLAB at DESY.

The iron valence state of HT-29 cells in different growing phases was also investigated. For these experiments the cells were trypsinized in the proper growing phase (lag, log or plateau) and prepared as mentioned above.

\subsubsection{Standards}

Different standard materials were selected focusing on the oxidation state, the ligand type and the coordination environment of the iron. $\mathrm{Fe}(\mathrm{II})$-citrate, $\mathrm{Fe}(\mathrm{II})-\alpha, \alpha^{\prime}$-dipyridyl, $\mathrm{K}_{4} \mathrm{Fe}(\mathrm{CN})_{6}, \mathrm{Fe}(\mathrm{III})$ $\mathrm{H}_{3} \mathrm{PO}_{4}, \mathrm{~K}_{3} \mathrm{Fe}(\mathrm{CN})_{6}, \mathrm{Fe}(\mathrm{III})$-citrate, $\mathrm{Fe}(\mathrm{III})$-EDTA and ferritin were used as $\mathrm{Fe}(\mathrm{II})$ and $\mathrm{Fe}(\mathrm{III})$ standards. All compounds (Reanal, Hungary and Sigma) were dissolved in deionised water to yield a concentration of $10 \mathrm{ppm}$ for iron and $1 \mu \mathrm{l}$ of these solutions containing $10 \mathrm{ng}$ of iron were pipetted directly onto the quartz reflectors.

\section{Results and discussion}

\subsection{Comparison of different Fe standards}

All measured Fe standards in comparison to published spectra of $\mathrm{FeCl}_{2}$ and $\mathrm{Fe}_{2} \mathrm{O}_{3}[32]$ are presented in Fig. 1. In order to find the best

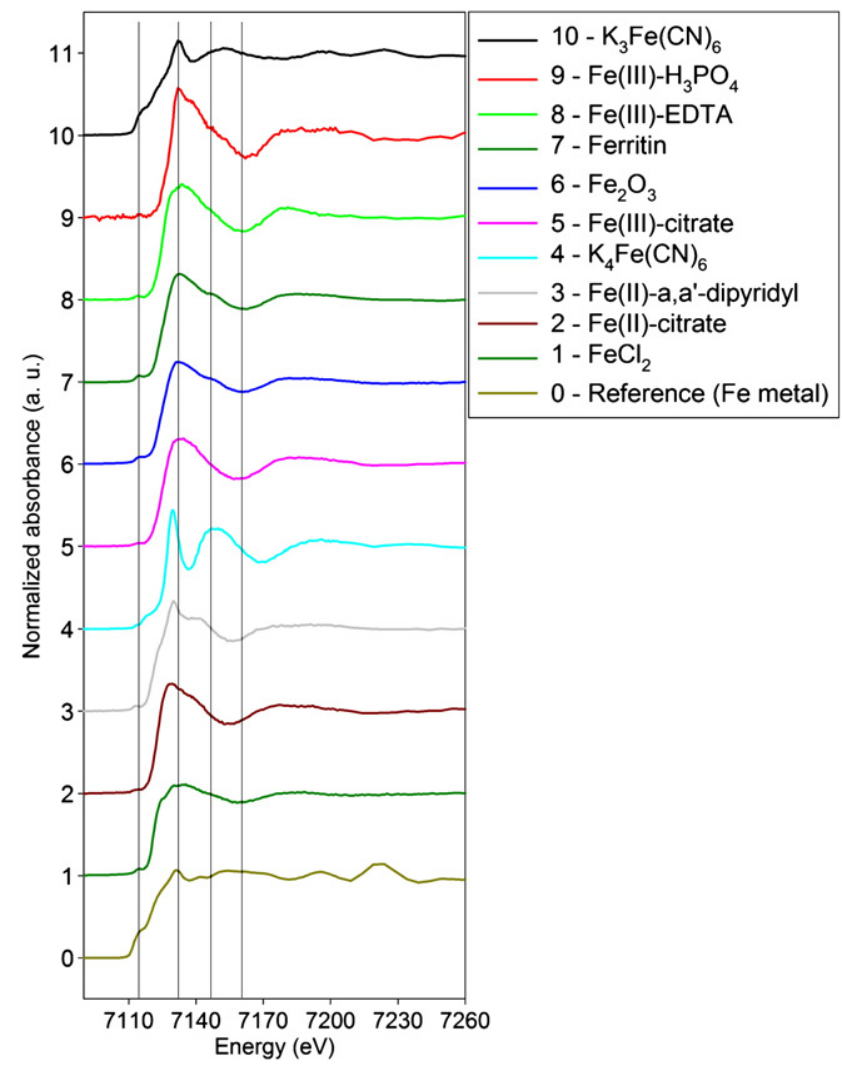

Fig. 1. XANES spectra of selected iron compounds compared to published spectra of $\mathrm{FeCl}_{2}$ and $\mathrm{Fe}_{2} \mathrm{O}_{3}$ which have been taken from the literature [32]. The gray lines indicate the energy positions of significant XANES features of Ferritin (pre-peak, whiteline, shoulder and first minimum) to show relative energy shifts between the standards measured.

fitting standard the main features of the samples have been marked by 4 vertical lines: 1 ) the pre-peak, 2 ) the white line, 3 ) the shoulder after the white line and 4 ) the first minimum. The spectra of oxidation state $3+$ and $2+$ can be clearly distinguished: the absorption edge of $\mathrm{Fe}$ (III) compounds coincides with that of $\mathrm{Fe}_{2} \mathrm{O}_{3}$, while the absorption edges of $\mathrm{Fe}(\mathrm{II})$-citrate and $\mathrm{FeCl}_{2}$ are similar. The spectrum of $\mathrm{Fe}(\mathrm{III})$ EDTA complex differs from that of $\mathrm{Fe}_{2} \mathrm{O}_{3}$, reflecting the very different chemical environment of iron, however the energy level of the absorption edge is rather similar. $\mathrm{Fe}(\mathrm{II})-\alpha, \alpha^{\prime}$-dipyridyl and $\mathrm{K}_{4} \mathrm{Fe}(\mathrm{CN})_{6}$ are displayed and compared with the $\mathrm{FeCl}_{2}$ and the $\mathrm{Fe}_{2} \mathrm{O}_{3}$ standards. The edge position of the $\mathrm{Fe}(\mathrm{II})-\alpha, \alpha^{\prime}$-dipyridyl coincides with the edge position of the $\mathrm{FeCl}_{2}$ standard. Surprisingly the absorption edge of the hexacyanoferrat sample lies at higher energies than the edge of $\mathrm{Fe}_{2} \mathrm{O}_{3}$ standard. A comparison of $\mathrm{K}_{4} \mathrm{Fe}(\mathrm{CN})_{6}$ spectrum with the literature data shows [33], that the main features of the spectrum are in good agreement (octahedral environment of the Fe centers by the $\mathrm{CN}$ groups). However, the compounds used are not identical and an exact comparison of the energy position of the edge is not possible. Regarding the oxidation state of Fe the authors reported an edge position energy shift of $\sim 1 \mathrm{eV}$ for the hexacyanoferrat containing $\mathrm{Fe}$ (III) compared to the ones containing $\mathrm{Fe}(\mathrm{II})$. In case of the $\mathrm{Fe}(\mathrm{III})-\mathrm{H}_{3} \mathrm{PO}_{4}$ standard a similar shift to higher energies can be observed. These phenomena are clear evidence of the changed environment of iron atom in different iron compounds.

\subsection{Comparison of ferritin and standards}

Fig. 2 shows the XANES spectrum of ferritin and the $\mathrm{Fe}_{2} \mathrm{O}_{3}$ standard. The edges of these spectra are very similar. This result is in agreement with the data from literature [22], however, the normalization method used by Ortega et al. was different. The similar spectra 


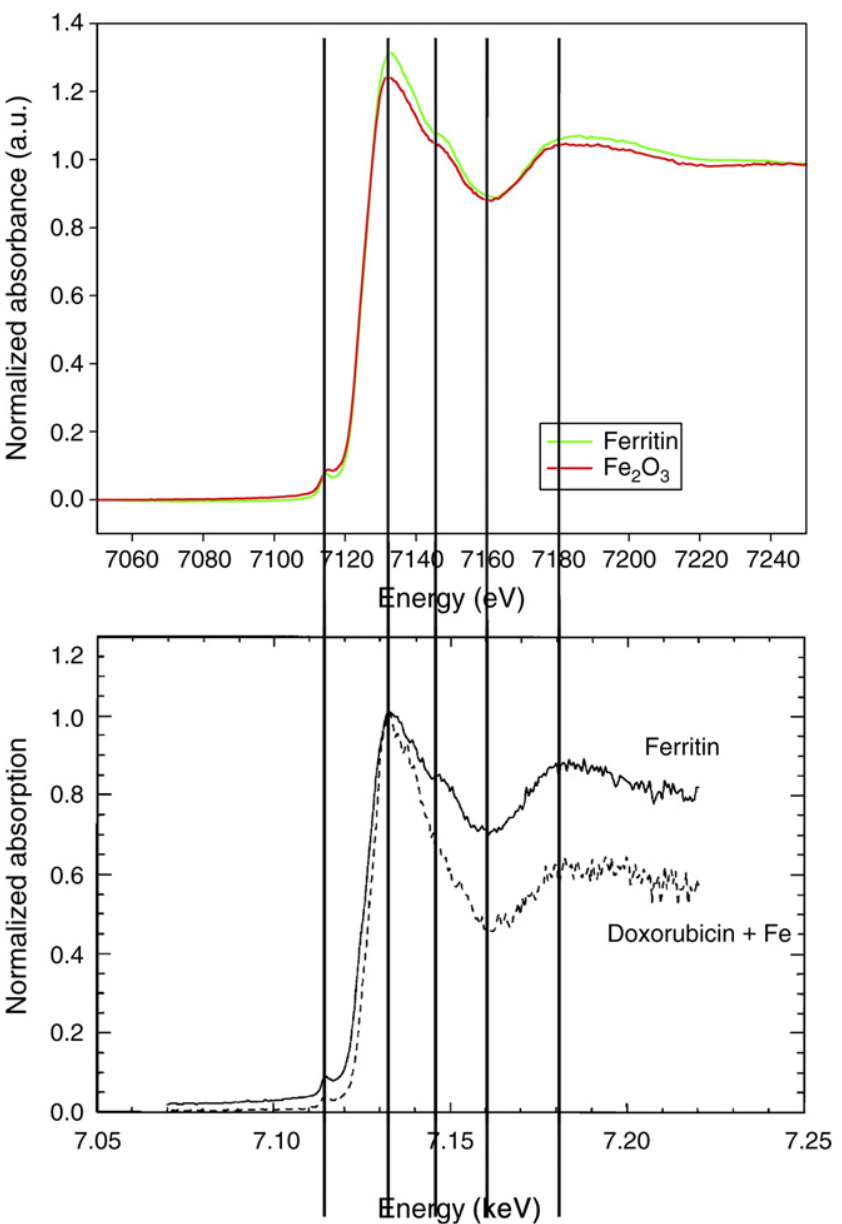

Fig. 2. Comparison of XANES spectra of ferritin and $\mathrm{Fe}_{2} \mathrm{O}_{3}$ standard (upper part) with a figure from literature (lower part) [22]. The main features of the XANES spectra of Ferritin are indicated by vertical black lines.

of ferritin and $\mathrm{Fe}_{2} \mathrm{O}_{3}$ demonstrate a similar environment for the $\mathrm{Fe}$ centers. Ferritin has the shape of a hollow sphere. Inside the sphere, iron is stored in $3+$ oxidation state. It is incorporated as mineral ferrihydrite, $[\mathrm{FeO}(\mathrm{OH})]_{8}\left[\mathrm{FeO}\left(\mathrm{H}_{2} \mathrm{PO}_{4}\right)\right]$, which is attached to the inner wall of the sphere. In case of iron release the oxidation state must be reduced from $3+$ to $2+$. Comparing with literature data [34] it seems that $\mathrm{Fe}$ in the ferritin sample investigated is most likely to be ferrihydrite (the different energy position of the edges is due to a different energy calibration).

\subsection{Impact of different sample preparation procedures on cell monolayer}

Two different sample preparation protocols were checked. First, quartz carrier plates were sterilized and incubated with different coating agents. Then, the cancer cells were seeded directly on the quartz reflectors. Second, the cell suspensions were pipetted onto quartz reflectors, as described in the Experimental section. Independently of the coating agent used, the first protocol resulted in a confluent cell layer on the quartz reflector, but it could not be declared as monolayer. Another drawback of the first procedure was that the cell number could be roughly estimated because only cells growing under the same conditions on a reference reflector can be trypsinized and counted. Although the second procedure is more laborious, the cell monolayer on the reflectors can be achieved, and verified by SEM measurements (Fig. 3A,B), and also the cell number can be exactly counted. The white spots that can be seen in both SEM images correspond to sodium chloride crystallized on the TXRF carriers. Isotonic sodium chloride solution is used for washing the cell cultures.

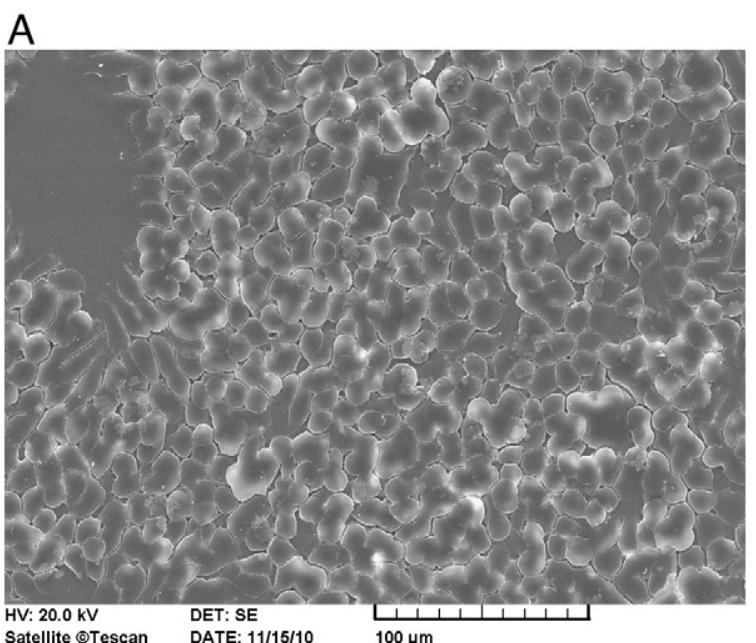

B

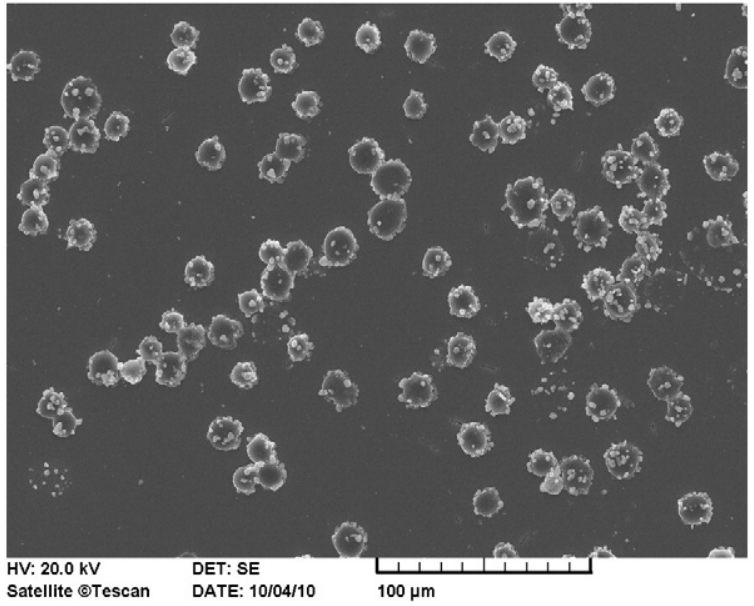

Fig. 3. SEM images for HT-29 cell samples: (A) cells were seeded on the quartz reflectors and $(B)$ cells were pipetted onto the reflectors. Operating conditions of the instrument: $10^{-4}$ mbar pressure; $20 \mathrm{kV}$ accelerating potential and $0.1 \mathrm{nA}$ current intensity.

Sodium chloride crsytals are in the same amount but in Fig. 3A, there are several cell layers due to the fact that they were grown on coating agents, meanwhile Fig. 3B corresponds to the pipetted cell suspensions, which turned out to be a monolayer.

The second procedure gives more reproducible results than the other procedure, and all further samples were measured in this way.

3.4. Investigation of XANES spectra of untreated and treated cells and standards to determine the oxidation state of $\mathrm{Fe}$

Intensive treatments were carried out for mimicking hypoxic state ( $\mathrm{Co}(\mathrm{II})$ or $\mathrm{Ni}(\mathrm{II}))$, inducing oxidative stress (5-FU), suspending the effect of $\mathrm{Co}(\mathrm{II})$ or 5-FU $\left(\mathrm{MgSO}_{4}\right)$ and inhibiting electron transfer chain (Antimycin A). Fig. 4 shows the XANES spectra of untreated and treated cells, as well as $\mathrm{Fe}(\mathrm{II})$ and $\mathrm{Fe}(\mathrm{III})$ standard samples. Remarkably, all spectra are almost the same indicating that the oxidation state of Fe in all cell samples is very similar. There is a concordance between the spectra of most of the samples (Fig. 4) and ferritin (Fig. 1). The main characteristics of XANES spectra are almost identical and the energy positions coincide. However the spectra of the samples are very similar to spectrum of ferritin, the spectra of Fe(III)EDTA and -citrate standard samples also show similar features.

An almost identical spectra was found for ferritin and one of the treated ( $\mathrm{Co}(\mathrm{II})+\mathrm{Mg}(\mathrm{II}))$ ZR-75-1 cell sample (Fig. 5). The spectra of cells treated with 5-fluorouracil and antimycin A only shows differences compared with that of ferritin standard. The edge position 


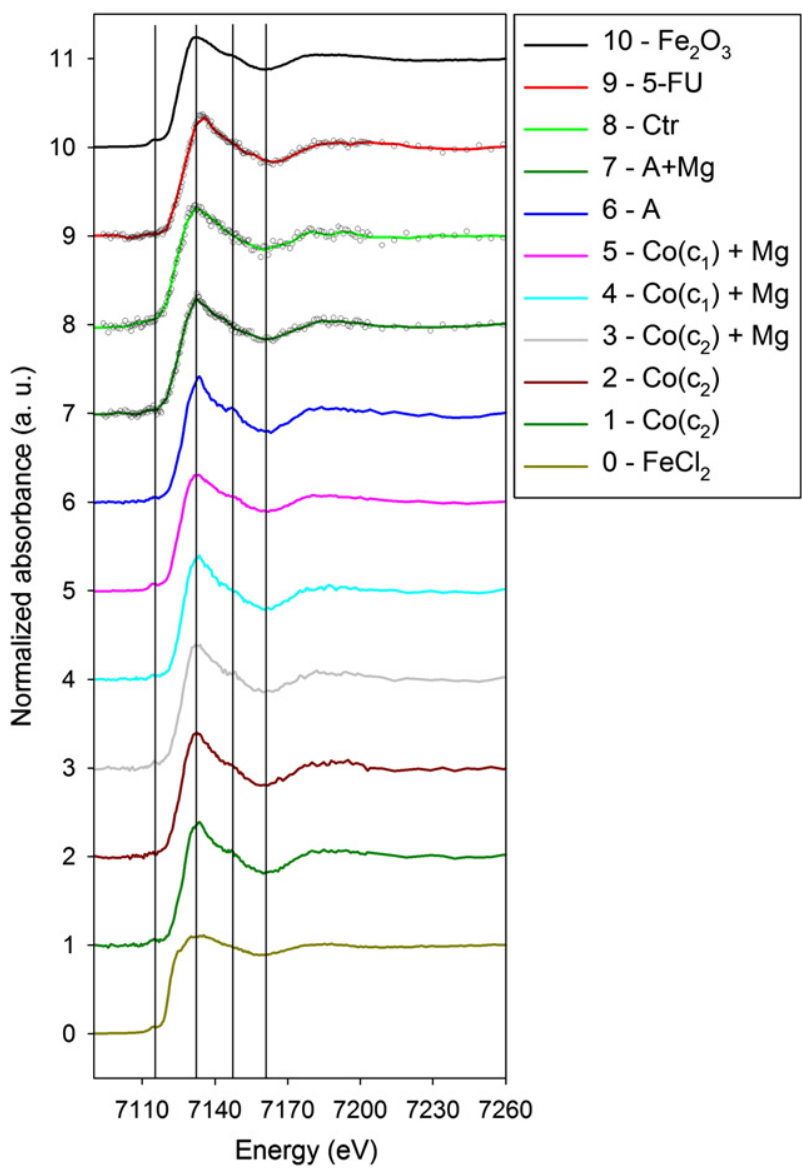

Fig. 4. XANES spectra of untreated and treated ZR-75-1 cancer cells compared with that of the $\mathrm{FeCl}_{2}$ and $\mathrm{Fe}_{2} \mathrm{O}_{3}$ standards. The gray lines indicate the energy positions of significant XANES features of Ferritin (pre-peak, whiteline, shoulder and first minimum) to show relative energy shifts between the standards measured. 5-FU $=130 \mu \mathrm{M}$ 5-fluorouracil; $\mathrm{Ctr}=$ control; $\mathrm{A}+\mathrm{Mg}=25 \mu \mathrm{M}$ antimycin $\mathrm{A}+10 \mathrm{mM} \mathrm{MgSO}_{4} ; \mathrm{A}=25 \mu \mathrm{M}$ antimycin $\mathrm{A}$; $\mathrm{Co}\left(\mathrm{c}_{1}\right)+\mathrm{Mg}=2.4 \mathrm{mMCoCl}_{2}+10 \mathrm{mM} \mathrm{MgSO}_{4} ; \mathrm{Co}\left(\mathrm{c}_{1}\right)+\mathrm{Mg}=2.4 \mathrm{mM} \mathrm{CoCl}_{2}+10 \mathrm{mM}$ $\mathrm{MgSO}_{4} ; \mathrm{Co}\left(\mathrm{c}_{2}\right)+\mathrm{Mg}=57.6 \mathrm{mM} \mathrm{CoCl}_{2}+10 \mathrm{mM} \mathrm{MgSO}_{4} ; \mathrm{Co}\left(\mathrm{c}_{2}\right)=57.6 \mathrm{mM} \mathrm{CoCl}_{2}$. The treatments lasted for $20 \mathrm{~min}$.

of 5-fluorouracil is shifted towards higher energies (i.e. higher oxidation state of Fe). The shape of the spectrum for $\mathrm{Fe}(\mathrm{II})-\alpha, \alpha^{\prime}-$ dipyridyl standard and that of antimycin A-treated cells is similar, however, the edge position of the antimycin $A$ is shifted to higher energies.

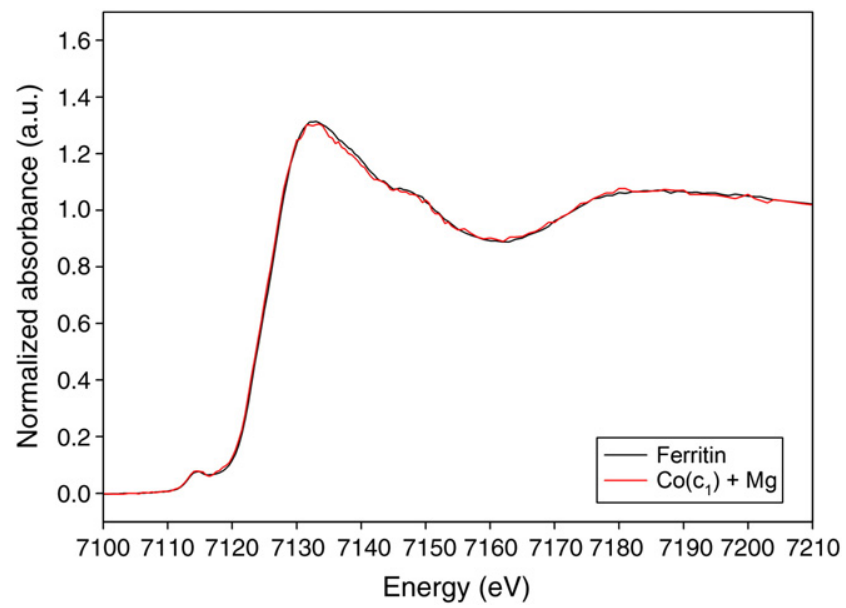

Fig. 5. Comparison of XANES spectrum of a ZR-75-1 cell sample and the ferritin standard. $\mathrm{Co}\left(\mathrm{c}_{1}\right)+\mathrm{Mg}=2.4 \mathrm{mM} \mathrm{CoCl}_{2}+10 \mathrm{mM} \mathrm{MgSO}_{4}$.
Comparing the XANES spectra of untreated samples, and that of Co- or Ni-treated samples or Co- and Mg-treated samples the similarity is outstanding and the edge position of the untreated sample is centered between the edge positions of treated samples $(\Delta \sim 0.5 \mathrm{eV})$. It can be concluded that no significant changes took place after $\mathrm{CoCl}_{2}$ or $\mathrm{NiCl}_{2}$ treatments. It is noted, that the treatments lasted for only $20 \mathrm{~min}$.

\subsection{Comparison of XANES spectra of different cells and growing phases of the cells}

Growth curve of cultured cells is divided into 3 parts: lag phase, log phase and plateau phase. In the lag phase, the cells enter a latent period of linear growth. This period lasts around $12-24 \mathrm{~h}$, and allows the cells to recover from trypsinization, reconstruct their cytoskeleton, secrete matrix to aid attachment, and spread out on the substrate, enabling them to reenter cell cycle. Then, they enter exponential growth in what is known as the log phase, during which the cell population doubles over a definable period, known as the doubling time and it is characteristic for each cell line. As the cell population becomes crowded when all of the substrate is occupied, the cells become packed, spread less on the substrate, and eventually withdraw from the cell cycle. Then, they enter the plateau or stationary phase where the growth is stopped.

Three adenocarcinoma (HT-29, ZR-75-1 and MDA-MB231) and one fibrosarcoma (HT-1080) cell lines spectra were recorded and compared. HT-29 samples have also been investigated during lag phase (phase of linear growth), log phase (phase of exponential growth) and the plateau phase. From the XANES analysis it can be concluded that the molecular environment of iron remained the same during all growth phases of the cells and there were no significant differences among the investigated cell lines (data not shown).

\subsection{Elemental analysis of cells by TXRF technique}

Our method enables the acquisition of TXRF and XANES spectra of the same samples. It is important to perform elemental (TXRF) analysis prior to XANES measurements mainly for two reasons: first, contaminated samples can be excluded prior to XANES analysis. Secondly, any metal treatment can be followed easily and the ratios of elements can be quantified without further analysis. For quantification $\mathrm{Zn}$ or $\mathrm{S}$ can be used as internal standard.

Fig. 6 shows the TXRF spectrum of the HT-29 cell line before and after the treatment with $\mathrm{NiCl}_{2}$. The Ni peak is absent for the untreated cells, but appears after the metal treatment. The different total counts can be explained by the different number of cells on the plates. The

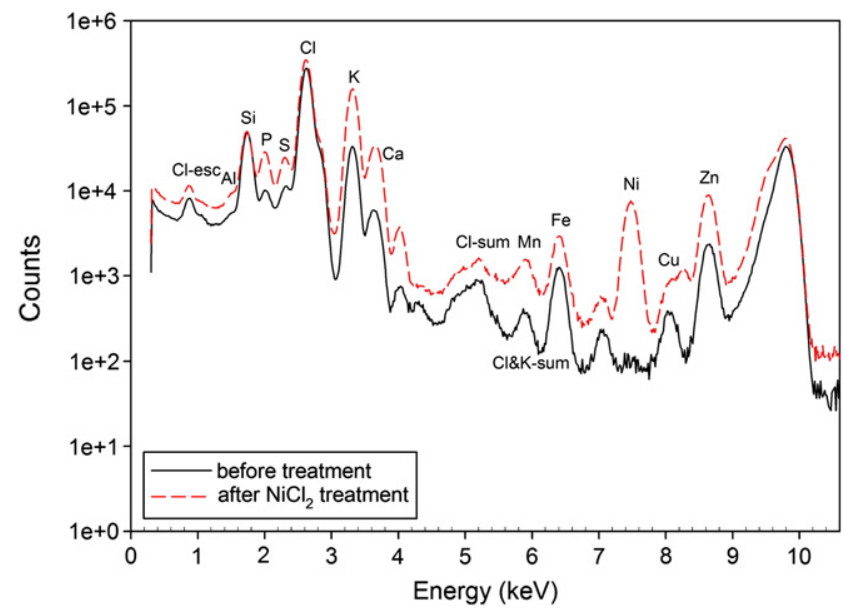

Fig. 6. Elemental (TXRF) spectrum of a HT-29 cells before (-) and after $1 \mathrm{mM} \mathrm{NiCl}_{2} 4 \mathrm{~h}$ treatment (---). 
exact quantification of each element did not constitute the aim of this work, but this problem can be solved by decomposition of another portion of the same sample and application of a suitable internal standard. It should be emphasized though, that without the need for XANES analysis (i.e. elemental analysis only), the required cell number can be reduced by one order of magnitude.

\section{Conlusion}

It was demonstrated that the SR-TXRF-XANES geometric arrangement is well applicable for XANES studies of iron in cell lines and qualitative or semiquantitative determination of elemental composition. The method is simple, relatively fast and the risk of contamination is minimal due to the small number of steps involved in sample preparation. A drawback of the procedure is that the cell layer should be checked for each sample by a microscope, and its thickness should not exceed that of a monolayer. The method is obviously applicable to study other important elements, like $\mathrm{Cr}, \mathrm{Co}, \mathrm{Ni}, \mathrm{Cu}$ or $\mathrm{Zn}$. For less complex objects, such as prepared cell organelles or isolated macromolecules the microscopic examination step can presumably be omitted.

\section{References}

[1] P. Wobrauschek, Total reflection X-ray fluorescence analysis - a review, X-ray Spectrom. 36 (2007) 289-300.

[2] N. Szoboszlai, Z. Polgári, V.G. Mihucz, G. Záray, Recent trends in total reflection X-ray fluorescence spectrometry for biological applications, Anal. Chim. Acta 633 (2009) $1-18$.

[3] P. Pianetta, N. Takaura, S. Brennan, W. Tompkins, S.S. Laderman, A. FischerColbrie, A. Shimazaki, K. Miyazaki, M. Madden, D.C. Wherry, J.B. Kortright, Totalreflection X-ray-fluorescence spectroscopy using synchrotron radiation for wafer surface trace impurity analysis, Rev. Sci. Instrum. 66 (1995) 1293-1297.

[4] C. Streli, P. Wobrauschek, F. Meirer, G. Pepponi, Synchrotron radiation induced TXRF - a critical review, J. Anal. Atom Spectrom. 23 (2008) 792-798.

[5] P. Wobrauschek, P. Kregsamer, W. Ladisich, C. Streli, S. Pahlke, L. Fabry, S. Garbe, M. Haller, A. Knochel, M. Radtke, TXRF with synchrotron-radiation analysis of Ni on Siwafer surfaces, Nucl. Instrum. Meth. A 363 (1995) 619-620.

[6] F. Comin, M. Navizet, P. Mangiagalli, G. Apostolo, An industrial SR-TXRF facility at ESRF, Nucl. Instrum. Meth. B 150 (1999) 538-542.

[7] P. Pianetta, K. Baur, A. Singh, S. Brennan, J. Kerner, D. Werho, J. Wang, Application of synchrotron radiation to TXRF analysis of metal contamination on silicon wafer surfaces, Thin Solid Films 373 (2000) 222-226.

[8] G. Falkenberg, G. Pepponi, C. Streli, P. Wobrauschek, Comparison of conventional and total reflection excitation geometry for fluorescence X-ray absorption spectroscopy on droplet samples, Spectrochim. Acta Part B 58 (2003) 2239-2244.

[9] C. Streli, G. Pepponi, P. Wobrauschek, C. Jokubonis, G. Falkenberg, G. Záray, A new SR-TXRF vacuum chamber for ultra-trace analysis at HASYLAB, Beamline L, X-ray Spectrom. 34 (2005) 451-455.

[10] F. Meirer, G. Pepponi, C. Streli, P. Wobrauschek, V.G. Mihucz, G. Záray, V. Czech, J.A.C. Broekaert, U.E.A. Fittschen, G. Falkenberg, Application of synchrotron-radiationinduced TXRF-XANES for arsenic speciation in cucumber (Cucumis sativus L.) xylem sap, X-Ray Spectrom. 36 (2007) 408-412.

[11] F. Meirer, G. Pepponi, C. Streli, P. Wobrauschek, P. Kregsamer, N. Zoeger, G. Falkenberg, Parameter study of self-absorption effects in total reflection X-ray fluorescence-X-ray absorption near edge structure analysis of arsenic, Spectrochim. Acta Part B 63 (2008) 1496-1502.

[12] M. González, L. Tapia, M. Alvarado, J.D. Tornero, R. Fernández, Intracellular determination of elements in mammalian cultured cells by total reflection X-ray fluorescence spectrometry, J. Anal. Atom Spectrom. 14 (1999) 885-888.

[13] N. Szoboszlai, A. Réti, B. Budai, Zs. Szabó, J. Kralovánszky, G. Záray, Direct elemental analysis of cancer cell lines by total reflection X-ray fluorescence, Spectrochim. Acta Part B 63 (2008) 1480-1484.
[14] Y. Huang, Y. Wu, L. Zhao, G. Li, W. He, L. Yuan, J. Chen, J. Li, T. Zhang, E. Cao, Beijing synchrotron radiation total-reflection X-ray fluorescence analysis facility and its applications on trace element study of cells, Spectrochim. Acta Part B 56 (2001) 2057-2062.

[15] J.G. Parsons, M.V. Aldrich, J.L. Gardea-Torresdey, Environmental and biological applications of extended X-ray absorption fine structure (EXAFS) and X-ray absorption near edge structure (XANES) spectroscopies, Appl. Spectrosc. Rev. 37 (2002) 187-222.

[16] W.M. Kwiatek, M. Podgórczyk, J. Dulinska-Litewka, P.M. Laidler, E. Welter, Zn K-edge XANES on prostate cancer cells, Hasylab Annual Report, 2007.

[17] W.M. Kwiatek, M. Podgórczyk, Cz. Paluszkiewicz, A. Balerna, A. Kisiel, Sulphur XANES analysis of cultured human prostate cancer cells, Acta Phys. Pol. A 114 (2008) 463-470.

[18] M.D. Hall, G.J. Foran, M. Zhang, P.J. Beale, T.W. Hambley, XANES determination of the platinum oxidation state distribution in cancer cells treated with platinum(IV) anticancer agents, J. Am. Chem. Soc. 125 (2003) 7524-7525.

[19] H.H. Harris, A. Levina, C.T. Dillon, I. Mulyani, B. Lai, Z. Cai, P.A. Lay, Time-dependent uptake, distribution and biotransformation of chromium(VI) in individual and bulk human lung cells: application of synchrotron radiation techniques, J. Biol. Inorg. Chem. 10 (2005) 105-118.

[20] A. Levina, H.H. Harris, P.A. Lay, X-ray absorption and EPR spectroscopic studies of the biotransformations of chromium(VI) in mammalian cells. Is chromodulin an artifact of isolation methods? J. Am. Chem. Soc. 129 (2007) 1065-1075.

[21] P.D. Bonnitcha, M.D. Hall, C.K. Underwood, G.J. Foran, M. Zhang, P.J. Beale, T.W. Hambley, XANES investigation of the Co oxidation state in solution and in cancer cells treated with Co(III) complexes, J. Inorg. Biochem. 100 (2006) 963-971.

[22] R. Ortega, G. Deves, S. Bohic, A. Simionovici, B. Menez, M. Bonnin-Mosbah, Iron distribution in cancer cells following doxorubicin exposure using proton and X-ray synchrotron radiation microprobes, Nucl. Instrum. Meth. B 181 (2001) 480-484.

[23] T. Bacquart, G. Deves, A. Carmona, R. Tucoulou, S. Bohic, R. Ortega, Subcellular speciation analysis of trace element oxidation states using synchrotron radiation micro-X-ray absorption near-edge structure, Anal. Chem. 79 (2007) 7353-7359.

[24] H. Chen, T. Davidson, S. Singleton, M.D. Garrick, M. Costa, Nickel decreases cellular iron level and converts cytosolic aconitase to iron-regulatory protein 1 in A549 cells, Toxicol. Appl. Pharmacol. 206 (2005) 275-287.

[25] Q. Li, H. Chen, X. Huang, M. Costa, Effects of 12 metal ions on iron regulatory protein 1 (IRP-1) and hypoxia-inducible factor-1 alpha (HIF-1 $\alpha$ ) and HIFregulated genes, Toxicol. Appl. Pharmacol. 213 (2006) 245-255.

[26] B. Sturm, T. Twaroch, B. Knapitsch, S. Czingraber, N. Ternes, H. Goldenberg, B. Scheiber-Mojdehkar, Differential response of iron metabolism to oxidative stress generated by antimycin A and nitrofurantoin, Biochimie 88 (2006) 575-581.

[27] A. Réti, G. Barna, E. Pap, V. Adleff, V.L. Komlósi, A. Jeney, J. Kralovánszky, B. Budai, Enhancement of 5-fluorouracil efficacy on high COX-2 expressing HCA-7 cells by low dose indomethacin and NS-398 but not on low COX-2 expressing HT-29 cells, Pathol. Oncol. Res. 15 (2009) 335-344.

[28] C. Streli, G. Pepponi, P. Wobrauschek, C. Jokubonis, G. Falkenberg, G. Záray, J. Broekaert, U. Fittschen, B. Peschel, Recent results of synchrotron radiation induced total reflection X-ray fluorescence analysis at HASYLAB, beamline L, Spectrochim. Acta Part B 61 (2006) 1129-1134.

[29] G. Falkenberg, Characterization of a radiant vortex silicon multi-cathode X-ray spectrometer for (total reflection) X-ray fluorescence applications, Hasylab Internal Report 2004, 2005.

[30] M. Newville, IFEFFIT: interactive XAFS analysis and FEFF fitting, J. Synchrotron Radiat. 8 (2001) 322-324.

[31] B. Ravel, M. Newville, ATHENA, ARTEMIS, HEPHAESTUS: data analysis for X-ray absorption spectroscopy using IFEFFIT, J. Synchrotron Radiat. 12 (2005) 537-541.

[32] U.E.A. Fittschen, F. Meirer, C. Streli, P. Wobrauschek, J. Thiele, G. Falkenberg, G. Pepponi, Characterization of atmospheric aerosols using synchroton radiation total reflection X-ray fluorescence and Fe K-edge total reflection X-ray fluorescenceX-ray absorption near-edge structure, Spectrochim. Acta Part B 63 (2008) 1489-1495.

[33] K.H. Hallmeier, S. Sauter, R. Szargan, XANES and EXAFS investigations of bonding and structure of $\mathrm{Ni}$ and $\mathrm{Co}$ derivatives from Prussian Blue coordination compounds, Inorg. Chem. Comm. 4 (2001) 153-156.

[34] M. Wilke, F. Farges, P.E. Petit, G.E. Brown, F. Martin, Oxidation state and coordination of Fe in minerals: an FeK-XANES spectroscopic study, Am. Mineral. 86 (2001) 714-730. 